\title{
Reevaluation of Neurodegeneration in lurcher Mice: Constitutive Ion Fluxes Cause Cell Death with, Not by, Autophagy
}

\author{
Jun Nishiyama, ${ }^{1,2}$ Keiko Matsuda, ${ }^{1}$ Wataru Kakegawa, ${ }^{1}$ Nobuaki Yamada, ${ }^{3}$ Junko Motohashi, ${ }^{1}$ Noboru Mizushima, ${ }^{4}$ \\ and Michisuke Yuzaki ${ }^{1}$ \\ ${ }^{1}$ Department of Physiology, School of Medicine, Keio University, Tokyo 160-8582, Japan, 2Department of Neuropsychiatry, Graduate School of Medicine, \\ University of Tokyo, Tokyo 113-0033, Japan, ${ }^{3}$ Ishikawa Sunrise Industries Creation Organization, Kanazawa 920-8203, Japan, and ${ }^{4}$ Department of \\ Physiology and Cell Biology, Tokyo Medical and Dental University, Tokyo 113-8519, Japan
}

The lurcher $(L c)$ mice have served as a valuable model for neurodegeneration for decades. Although the responsible mutation was identified in genes encoding $\delta 2$ glutamate receptors (GluD2s), which are predominantly expressed in cerebellar Purkinje cells, how the mutant receptor $\left(\mathrm{GluD}^{\mathrm{LC}}{ }^{\mathrm{LC}}\right)$ triggers cell death has remained elusive. Here, taking advantage of recent knowledge about the domain structure of GluD2, we reinvestigated Lc-mediated cell death, focusing on the "autophagic cell death" hypothesis. Although autophagy and cell death were induced by the expression of GluD2 ${ }^{\mathrm{Lc}}$ in heterologous cells and cultured neurons, they were blocked by the introduction of mutations in the channel pore domain of $\mathrm{GluD} 2{ }^{\mathrm{Lc}}$ or by removal of extracellular $\mathrm{Na}^{+}$. In addition, although $\mathrm{GluD} 2{ }^{\mathrm{Lc}}$ is reported to directly activate autophagy, mutant channels that are not associated with n-PIST (neuronal isoform of protein-interacting specifically with TC10)-Beclin1 still caused autophagy and cell death. Furthermore, cells expressing GluD2 ${ }^{\mathrm{Lc}}$ showed decreased ATP levels and increased AMP-activated protein kinase (AMPK) activities in a manner dependent on extracellular $\mathrm{Na}^{+}$. Thus, constitutive currents were likely necessary and sufficient to induce autophagy via AMPK activation, regardless of the n-PIST-Beclin1 pathway in vitro. Interestingly, the expression of dominant-negative AMPK suppressed $\mathrm{GluD}_{2}{ }^{\mathrm{Lc}}$-induced autophagy but did not prevent cell death in heterologous cells. Similarly, the disruption of $A \operatorname{tg} 5$, a gene crucial for autophagy, did not prevent but rather aggravated Purkinje-cell death in $L c$ mice. Furthermore, calpains were specifically activated in $L c$ Purkinje cells. Together, these results suggest that Lc-mediated cell death was not caused by autophagy but necrosis with autophagic features both in vivo and in vitro.

\section{Introduction}

The lurcher $(L c)$ mouse is an autosomal semidominant mutant originally described five decades ago (Vogel et al., 2006). In heterozygous mice $(\mathrm{Lcl}+)$, cerebellar Purkinje cells specifically start to degenerate in a cell-autonomous manner by postnatal day 8 (P8), and most die during the second postnatal week; other cell types are eventually affected by secondary mechanisms (Wetts and Herrup, 1982). Lcl + mice show prominent ataxic gait and poor rotarod performance during the third postnatal week, when about $90 \%$ of the Purkinje cells have disappeared. $L c$ is caused by a point mutation in the $\delta 2$ glutamate receptor (GluD2) (Zuo et al., 1997), which is predominantly expressed in cerebellar Purkinje cells. Because of this well-defined genetic lesion that affects a single cell type and causes obvious behavioral changes in vivo,

Received Dec. 6, 2009; accepted Dec. 24, 2009

This work was supported by grants-in-aid from the Ministry of Education, Culture, Sports, Science and Technology of Japan (M.Y.), the Japan Society for the Promotion of Science (J.N.), the Takeda Science Foundation (M.Y.), and the Sankyo Foundation of Life Science (M.Y.). We thank Sakae Narumi for technical assistance.

The authors declare no competing financial interests.

Correspondence should be addressed to Michisuke Yuzaki, Department of Physiology, School of Medicine, Keio University, 35 Shinanomachi, Shinjuku-ku, Tokyo 160-8582, Japan. E-mail: myuzaki@a5.keio.jp.

DOI:10.1523/JNEUROSCI.6030-09.2010

Copyright $\odot 2010$ the authors $\quad 0270-6474 / 10 / 302177-11 \$ 15.00 / 0$ the $L c$ mouse has served as a valuable model for studying the mechanisms of neurodegeneration.

Despite the identification of the responsible mutation in $L c$ mice, the mechanisms by which Purkinje cells die have remained elusive. Cell death was originally thought to be caused by excitotoxicity (Seeburg, 1997); continuous $\mathrm{Na}^{+}$and some $\mathrm{Ca}^{2+}$ ions passing through constitutively open GluD2 ${ }^{\mathrm{Lc}}$ channels were thought to depolarize $L c$ Purkinje cells and to activate various cell-death execution pathways. Later, wild-type GluD2 (GluD2 ${ }^{\mathrm{wt}}$ ) was shown to interact via its C terminus with the PSD-95/Dlg/ ZO-1 (PDZ)-domain-containing protein n-PIST (neuronal isoform of protein-interacting specifically with TC10); this protein binds to Beclin1, a mammalian ortholog of yeast Atg6 (Kihara et al., 2001), thereby regulating the formation of autophagosomes. The expression of GluD2 ${ }^{\mathrm{Lc}}$, but not GluD2 ${ }^{\mathrm{wt}}$, in heterologous cells was shown to lead to the formation of Beclin1-positive autophagosome-like vesicles and to an increase in cell death (Yue et al., 2002). Indeed, electron microscopic and immunohistochemical analyses revealed autophagosomes in $L c /+$ Purkinje cells. Interestingly, Purkinje cells in Lc/ho mice, in which a copy of the wild-type allele in $\mathrm{Lcl}+$ mice was replaced with a null allele (ho), died earlier than those in $L c /+$ mice, despite the fact that the Lc/ho Purkinje cells were less depolarized (Selimi et al., 2003). 
These findings led to an "autophagic cell death" hypothesis, in which the $L c$ mutation activates GluD2 so that Beclin 1 is released to activate autophagy constitutively, leading to cell death in a manner that is independent of depolarization. Indeed, $L c /+$ mutant mice have been cited as an example of cell death resulting from autophagy (Shintani and Klionsky, 2004; Rubinsztein et al., 2005). Nevertheless, how the moderate autophagic features observed in $L c /+$ Purkinje cells would be sufficient to activate the massive cell death during the second postnatal week has been unclear (Dusart et al., 2006). In addition, a channel blocker was recently shown to block $L c /+$ Purkinje cell death in cultured cerebellar slices (Zanjani et al., 2009); whether autophagy is involved in this form of cell death remains unclear. Here, taking advantage of recent knowledge about the domain structure of GluD2 ${ }^{\text {wt }}$ (Yuzaki, 2008), we reinvestigated Lc-mediated cell death in heterologous cells and cultured neurons as well as in $L c$ mice in vivo. We showed that Lc-mediated cell death was unlikely to be caused by autophagy; rather, constitutive ion flux per se caused excitotoxic cell death with autophagic features independent of the n-PIST-Beclin1 pathway.

\section{Materials and Methods}

Animals. Purkinje-cell-specific Atg5-deficient mice (Atg $5^{\text {flox/flox}}$; pcp2$\mathrm{Cre}$ ) were generated as described previously (Nishiyama et al., 2007) and crossed with $L c /+$ mice (B6CBACa $A^{w-J} / A-G r i d 2^{L c} / J$; The Jackson Laboratory). GluD2 ${ }^{\text {wt }}$ and GluD2 ${ }^{\text {wt }}-\Delta \mathrm{CT} 7$ transgenic mice on a GluD2-null background were generated as described previously (Kakegawa et al., 2008). Genotypes were determined by PCR analysis of genomic DNA from mouse tail (Nishiyama et al., 2007). For genotyping the $L c /+$ allele, exon 12 of the GluD2 gene was amplified by PCR using a forward primer (5'-GTT GTC TGT CTT GGC ACT GA-3') and a reverse primer (5'ATG TGC AGA GGG CTT TCC TT- $3^{\prime}$ ) and subjected to digestion by a restriction endonuclease Fnu4HI (Bio-Rad). All procedures relating to the care and treatment of the animals were performed in accordance with the National Institutes of Health (NIH) guidelines. The animals were killed by decapitation after anesthetization with tribromoethanol.

cDNA constructs. Site-directed mutagenesis was accomplished using the overlap extension PCR method to introduce mutations to cDNAs encoding GluD2 and GluK2. The cDNAs encoding enhanced green fluorescent protein (EGFP) and mCherry were kindly provided by Dr. R. Y. Tsien (University of California, San Diego, La Jolla, CA). We added cDNA encoding EGFP to the 5' ends of a mammalian Atg8 ortholog LC3 and a mammalian Atg6p/Vps30p ortholog Beclin1 to produce EGFPLC3 and EGFP-Beclin1, respectively. The nucleotide sequence of the amplified open reading frame was confirmed using bidirectional sequencing. The cDNAs were subcloned into the expression vector pCAGGS (provided by Dr. J. Miyazaki, Osaka University, Osaka, Japan). The expression vectors for dominant-negative AMP-activated protein kinase (AMPK) $\alpha$ (Woods et al., 2000; Mu et al., 2001), pcDNA3-MycAMPK $\alpha 1-D 157 \mathrm{~A}$, and pcDNA3-Myc-AMPK $\alpha 2-\mathrm{K} 45 \mathrm{R}$ were generous gifts from Drs. D. Carling (Imperial College, London, UK) and M. Birnbaum (University of Pennsylvania, Philadelphia, PA), respectively.

Cell culture, transfection, and immunocytochemistry. Human embryonic kidney 293 (HEK293) cells (CRL-1573; American Type Culture Collection) were maintained in $10 \% \mathrm{CO}_{2}$ at $37^{\circ} \mathrm{C}$ in DMEM (Invitrogen) supplemented with $10 \%$ fetal bovine serum (Hyclone). One day before transfection, $0.5 \times 10^{5}$ cells were plated on poly-L-lysine-coated $12 \mathrm{~mm}$ coverslips. The cells were then transfected with a total of $1 \mu \mathrm{g}$ of plasmids (the ratio of pCAGGS-GluD2 to pEGFP-LC3 was 3:1) using Lipofectamine 2000 (Invitrogen). To evaluate the ion dependency of Lcmediated autophagy and cell death, the culture medium was changed to artificial CSF (ACSF) containing various concentrations of $\mathrm{Na}^{+}$or $\mathrm{Ca}^{2+}$ at $6 \mathrm{~h}$ after transfection. Low- $\mathrm{Na}^{+}$-containing ACSF was prepared by replacing $\mathrm{Na}^{+}$with equimolar $\mathrm{N}$-methyl-D-glucosamine ${ }^{+}\left(\mathrm{NMDG}^{+}\right)$ in ACSF [150 mM NaCl, $5 \mathrm{~mm} \mathrm{KCl} \mathrm{5,} 2 \mathrm{~mm} \mathrm{CaCl}_{2}, 1 \mathrm{~mm} \mathrm{MgCl}_{2}, 20 \mathrm{~mm}$ D-glucose, B-27 (Invitrogen), and 20 mM HEPES, pH 7.3, with KOH]. To prepare high-Ca ${ }^{2+}$-containing ACSF, $\mathrm{NaCl}$ was reduced to $50 \mathrm{~mm}$, and the osmolarity was adjusted with sucrose. Cells were fixed with $4 \%$ paraformaldehyde at the indicated time points.

Dissociated cultures of hippocampal neurons were prepared from embryonic day 17 to 18 mice as described previously (Forrest et al., 1994), and kept in Neurobasal medium supplemented with B-27 and L-glutamine (Invitrogen). Cultured hippocampal neurons were transfected with plasmids encoding mCherry and GluD2 mutants with or without EGFP-LC3 using Lipofectamine 2000 at $12 \mathrm{~d}$ in vitro (DIV). The ratio of the three plasmids was 1:1:1 or 1:2:0. At $15 \mathrm{~h}$ after transfection, the neurons were fixed with $4 \%$ paraformaldehyde and washed with PBS. The cultures were first incubated with a blocking solution ( $2 \%$ goat serum, $2 \%$ bovine serum albumin (BSA), and $0.4 \%$ Triton X-100 in PBS) and were then incubated with rat anti-GluD2 (dilution, 1:300), chicken anti-GFP (dilution, 1:1000; Millipore), rabbit anti-MAP2 (dilution, 1:1000; Millipore), or mouse anti-Tau-1 (dilution, 1:200; Millipore). For visualization, secondary antibodies conjugated to 488 or 350 (diluted at 1:1000; Invitrogen) were used.

Quantification of autophagy and cell death in vitro. For the quantification of autophagic activity in vitro, EGFP-LC3 fluorescence images were captured using a CCD camera (DP 70; Olympus) attached to a fluorescence microscope (BX60; Olympus). The number of vesicular structures of EGFP-LC3 in a cell was counted using a linear filter followed by an object detection algorithm using IPLab Spectrum 3.6 software (Signal Analytics) (supplemental Fig. $1 \mathrm{~A}$, available at www.jneurosci.org as supplemental material). For the quantification of cell death in vitro, the number of surviving cells was estimated by counting the EGFP-emitting signals on the coverslips. In addition, cell death was analyzed by propidium iodide (PI; Invitrogen) staining according to the manufacturer's protocol. Briefly, HEK293 cells were stained with $1 \mu \mathrm{g} / \mathrm{ml}$ PI for $10 \mathrm{~min}$ at room temperature, washed with PBS, and immediately examined under the fluorescent microscope. The quantification of cell death by PI staining (supplemental Fig. $1 B, C$, available at www.jneurosci.org as supplemental material) matched well with that by EGFP signals shown in main figures. Cellular ATP levels were measured using the ATP Bioluminescent Somatic Cell Assay Kit (Sigma-Aldrich) according to the manufacturer's protocol.

Calcium imaging. One day before transfection, $1 \times 10^{5}$ HEK293 cells were plated on poly-L-lysine-coated $18 \mathrm{~mm}$ coverslips. The cells were transfected with $2.0 \mu \mathrm{g}$ of pCAGGS-GluD2 or mutant GluD2s using Lipofectamine 2000. At 8, 14, and $23 \mathrm{~h}$ after transfection, the cells were loaded with $2 \mu \mathrm{M}$ fura- $2 \mathrm{AM}$ (Invitrogen) in culture medium for $45 \mathrm{~min}$ at $37^{\circ} \mathrm{C}$. After incubation, fura-2-loaded cells were placed in an experimental chamber, washed three times, and resuspended in ACSF. Following a $10-20 \mathrm{~min}$ de-esterification period, the cells were alternately excited at $340 \mathrm{~nm}$ (F340) and $380 \mathrm{~nm}$ (F380; exposure times of $400 \mathrm{~ms}$ and $100 \mathrm{~ms}$, respectively) using a motorized filter wheel (Lambda 10-2; Sutter Instrument). Fluorescence emissions at $510 \mathrm{~nm}$ were captured with a cooled CCD digital camera (PXL; Photometric). The acquired images were analyzed using IPLab Spectrum 3.6 software, and the fluorescence intensity ratio F340/F380 was calculated. To identify the cells expressing GluD2 or mutant GluD2s, an immunohistochemical analysis was performed after the fura- 2 measurements. Cells were fixed with $4 \%$ paraformaldehyde for $10 \mathrm{~min}$ at room temperature and incubated with a blocking solution for $1 \mathrm{~h}$. The cells were then incubated with rat antiGluD2 (dilution, 1:300) for $1 \mathrm{~h}$. To visualize the bound primary antibody, the cells were incubated with Alexa 546-conjugated anti-rabbit antibodies (diluted 1:1000; Invitrogen).

Western blot analysis. Nine hours and $15 \mathrm{~h}$ after transfection, HEK293 cells were washed with PBS, lysed in $1 \times$ SDS sample buffer $(62.5 \mathrm{~mm}$ Tris-HCl, $2 \%$ SDS, $10 \%$ glycerol, 50 mm DTT, $0.01 \%$ bromophenol blue) and incubated at $95^{\circ} \mathrm{C}$ for $5 \mathrm{~min}$. The lysate was sonicated for $15 \mathrm{~s}$ and microcentrifuged for $2 \mathrm{~min}$ at $4^{\circ} \mathrm{C}$. Whole cerebella of wild-type and $L c$ mice were homogenized by glass/Teflon homogenizer, and solubilized in $500 \mu \mathrm{l}$ TNE buffer (50 mu NaF, $1 \%$ NP-40, 20 mM EDTA, $1 \mu \mathrm{m}$ pepstatins, $2 \mu \mathrm{g} / \mathrm{ml}$ leupeptin, $10 \mu \mathrm{g} / \mathrm{ml}$ aprotinin, $0.1 \%$ SDS, $50 \mathrm{~mm}$ Tris$\mathrm{HCl}, \mathrm{pH} 8.0)$ for $1 \mathrm{~h}$ at $4^{\circ} \mathrm{C}$. Soluble and insoluble fractions were separated by centrifugation at $11,500 \times g$ for $20 \mathrm{~min}$. Both fractions were incubated in SDS-PAGE sample buffer for $5 \mathrm{~min}$ at $95^{\circ} \mathrm{C}$. After centrifugation, the supernatant was loaded onto SDS-polyacrylamide gels. 
A

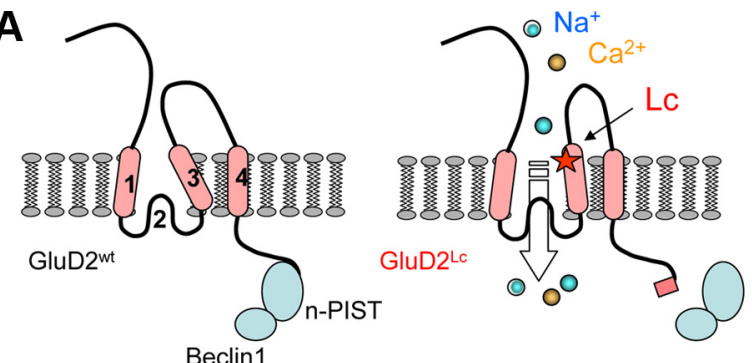

B

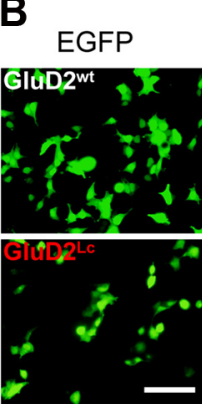

D

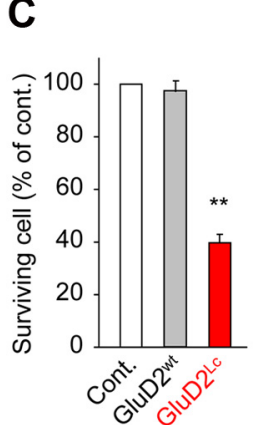

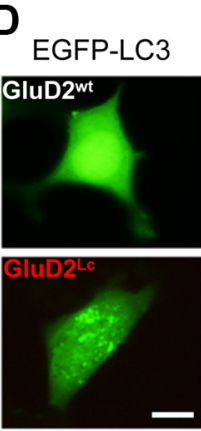

E

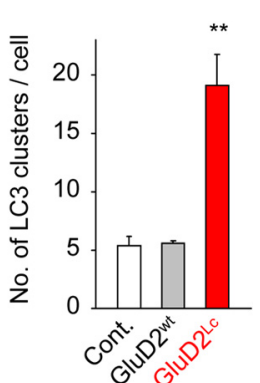

Figure 1. Induction of autophagy and cell death in HEK293 cells expressing GluD2 ${ }^{\mathrm{Lc}}$. A, Schematic diagrams of GluD2 ${ }^{\text {wt }}$ and GluD2 ${ }^{\mathrm{Lc}}$. The numbers indicate transmembrane domains $1-4$. In $\mathrm{GluD2}^{\mathrm{Lc}}$, a point mutation in the third transmembrane domain (red star) turns the channel constitutively open and allows $\mathrm{Na}^{+}$and $\mathrm{Ca}^{2+}$ flow into the cells (open arrow). The pink box at the C-terminal end indicates the C-terminal PDZ ligand region, which associates with Beclin1 via n-PIST. $\boldsymbol{B}$, Representative fluorescence images of HEK293 cells expressing EGFP and either GluD2 ${ }^{\text {wt }}$ or GluD2 ${ }^{\mathrm{Lc}}$. C, Cell death induced by GluD2 ${ }^{\mathrm{Lc}}$. At $15 \mathrm{~h}$ after transfection, the number of EGFP-positive cells was counted and normalized by that in control cells (Cont.; mock transfected). Error bars indicate the mean \pm SEM (from 3 independent experiments). D, Representative fluorescence images of HEK293 cells expressing EGFP-LC3 and either GluD2 ${ }^{\mathrm{wt}}$ or GluD2 ${ }^{\mathrm{Lc}}$. $\boldsymbol{E}$, Autophagosome formation induced by GluD2 ${ }^{\mathrm{Lc}}$. The number of EGFP-LC3 puncta, as a marker for autophagosomes, was counted in each cell coexpressing $\mathrm{GluD2}^{\mathrm{wt}}$ or $\mathrm{GluD2}{ }^{\mathrm{Lc}}$ using the object detection algorithm (see Materials and Methods). Error bars indicate the mean + SEM (from at least 60 cells in 3 independent experiments). Scale bars: $B, 100 \mu \mathrm{m} ; \boldsymbol{D}, 10 \mu \mathrm{m} .{ }^{* *} p<0.01$.

The proteins were transferred to polyvinylidene difluoride membranes (Immobilon-P; Millipore) and were allowed to react with antiAMPK $\alpha$, anti-AMPK $\alpha$ phosphothreonine 172-specific antibody (Cell Signaling Technology), anti-LC3 polyclonal antibody (Kabeya et al., 2000 ), anti-actin (Sigma), or an anti-136 kDa fragment of $\alpha$-spectrin cleaved by calpain (kindly provided by Dr. T. C. Saido, Laboratory for Proteolytic Neuroscience, RIKEN Brain Science Institute, Saitama, Japan). Proteins were visualized using the chemiluminescence detection system ECL Plus (GE Healthcare).

Immunohistochemistry and quantification of cell death and axon swelling in cerebellar slices. Under deep anesthesia, the mice were fixed by cardiac perfusion with $0.1 \mathrm{~m}$ sodium phosphate buffer (PB), $\mathrm{pH}$ 7.4, containing $4 \%$ paraformaldehyde (4\% PFA/PB). The cerebellum was then removed and soaked in $4 \% \mathrm{PFA} / \mathrm{PB}$ for over $4 \mathrm{~h}$. After rinsing the specimens with PBS, parasagittal slices $(100 \mu \mathrm{m})$ were prepared using a microslicer (DTK-2000; Dosaka) and were permeabilized with $0.2 \%$ Triton X-100 in PBS with $2 \%$ normal goat serum and $2 \%$ BSA for $6 \mathrm{~h}$ at $4^{\circ} \mathrm{C}$. Immunohistochemical staining was performed using antibodies against calbindin (1:1000; Millipore), synaptophysin (1:500; Sigma), or anti-136 $\mathrm{kDa}$ fragment of $\alpha$-spectrin cleaved by calpain $(1: 1000)$ at $4^{\circ} \mathrm{C}$, followed by incubation with Alexa 488- and Alexa 546-conjugated secondary antibodies. The stained slices were viewed using a confocal laser-scanning microscope (Fluoview; Olympus). For quantification of Purkinje cell death in cerebellar slices, the number of Purkinje cells was quantified from four lobules (lobules III, IV, VIII, and IX) using NIH Image software (Scion) as described previously (Nishiyama et al., 2007). For the quantification of axon terminal swelling of Purkinje cells, fluorescent images immunostained by anti-calbindin (a Purkinje cell marker) and anti-synaptophysin (a presynaptic marker) antibodies in the deep cerebellar nucleus (DCN) region were acquired. The area of Purkinje cell axons that were double immunopositive for calbindin and synaptophysin was calculated using a linear filter followed by an object detection algorithm using the IPLab Spectrum 3.6.

Data analysis and statistics. The results are presented as the means \pm SEM, and the statistical significance was defined as $p<0.05$ using the unpaired Student's $t$ test.

\section{Results \\ In vitro system to monitor Lc-mediated cell death and autophagy}

To better characterize Lc-mediated cell death in vitro, we coexpressed GluD2 ${ }^{\mathrm{Lc}}$ or GluD2 ${ }^{\text {wt }}$ with EGFP in HEK293 cells (Fig. $1 A)$. The number of EGFP-positive cells expressing GluD2 ${ }^{\mathrm{Lc}}$ was significantly less than those expressing GluD2 ${ }^{\text {wt }}$ or none (mock) at $15 \mathrm{~h}$ after transfection (Fig. $1 B, C)$. Similarly, the number of PI-positive dead cells was significantly increased in HEK293 cells expressing GluD2 ${ }^{\mathrm{Lc}}$ than those expressing GluD2 ${ }^{\text {wt }}$ (supplemental Fig. $1 B, C$, available at www.jneurosci.org as supplemental material). Next, to examine whether this type of cell death involved autophagy, we cotransfected HEK293 cells with GluD2 ${ }^{\text {wt }}$, GluD2 ${ }^{\text {Lc }}$, or mock with EGFP-tagged LC3 (EGFP-LC3), a mammalian ortholog of yeast Atg8, which is strongly associated with autophagosomes. Cells expressing GluD2 ${ }^{\mathrm{Lc}}$ displayed numerous EGFP-LC3-positive intracellular puncta at $15 \mathrm{~h}$ after transfection (Fig. 1D); the number of EGFP-LC3 puncta was significantly higher in GluD2 ${ }^{\mathrm{Lc}}$-transfected cells than in mock-transfected or GluD2 ${ }^{\mathrm{wt}}$ transfected cells (Fig. 1E). As reported previously (Yue et al., 2002), GluD2 ${ }^{\mathrm{Lc}}$ also induced EGFPBeclin1 clusters in HEK293 cells (supplemental Fig. 2, available at www.jneurosci.org as supplemental material); however, Beclin1 is only involved in the early phase of autophagy and is not tightly associated with autophagosomes. Therefore, using LC3 as a more specific marker for autophagosomes, these findings confirmed that Lc-mediated cell death and autophagosome formation were recapitulated in heterologous cells in vitro.

\section{Currents carried by $\mathrm{Na}^{+}$, but not $\mathrm{Ca}^{2+}$, are necessary for Lc-mediated autophagy and cell death}

Constitutive currents associated with GluD2 ${ }^{\mathrm{Lc}}$ are mainly carried by monovalent cations, such as $\mathrm{Na}^{+}$and $\mathrm{K}^{+}$, but also by some $\mathrm{Ca}^{2+}$ ions (Kohda et al., 2000; Wollmuth et al., 2000). To examine the role of constitutive currents in Lc-mediated cell death and autophagy, we introduced mutations to the channel pore domain of GluD2 ${ }^{\mathrm{Lc}}$ (Fig. 2A). GluD2 contains a glutamine (Q) residue at the $\mathrm{Q} / \mathrm{R}$ site of the channel pore domain; these residues at the equivalent position determine the $\mathrm{Ca}^{2+}$ permeability of AMPA or kainate receptors. Similarly, GluD2 ${ }^{\mathrm{Lc}}-\mathrm{Q} 618 \mathrm{R}$, in which arginine $(\mathrm{R})$ is substituted for $\mathrm{Q}$ at the $\mathrm{Q} / \mathrm{R}$ site, became essentially impermeable to $\mathrm{Ca}^{2+}$ (Kohda et al., 2000; Wollmuth et al., 2000). Nevertheless, GluD2 ${ }^{\mathrm{Lc}}$ and GluD2 ${ }^{\mathrm{Lc}}$-Q618R induced a similar number of EGFP-LC3 puncta in HEK293 cells at $15 \mathrm{~h}$ after transfection (Fig. 2B). Although cell death was delayed in HEK293 cells expressing GluD2 ${ }^{\mathrm{Lc}}-\mathrm{Q} 618 \mathrm{R}$ than in those expressing GluD2 ${ }^{\mathrm{Lc}}$, most cells eventually died at $36 \mathrm{~h}$ after transfection (Fig. $2 C)$. The delay in cell death may have been caused by the lower current amplitudes in HEK293 cells expressing GluD2 ${ }^{\mathrm{Lc}}$-Q618R 
than in those expressing GluD2 ${ }^{\mathrm{Lc}}$ (Kohda et al., 2000) (see below). These results suggest that $\mathrm{Ca}^{2+}$ ion flows were dispensable for autophagosome formation and death in cells expressing $\mathrm{GluD} 2{ }^{\mathrm{Lc}}$.

The arginine substitution of a hydrophobic residue, which is located one position upstream of the $\mathrm{Q} / \mathrm{R}$ site, disrupts the channel pore of AMPA and kainate receptors (Dingledine et al., 1992; Robert et al., 2002). Similarly, GluD2 ${ }^{\text {Lc }}-$ V617R, in which $\mathrm{R}$ is substituted for valine $(\mathrm{V})$ at one position upstream of the $\mathrm{Q} / \mathrm{R}$ site (Fig. $2 A$ ), prevented all ion flow through the channel despite its expression on the cell surface (Kakegawa et al., 2007). Interestingly, the expression of GluD2 ${ }^{\mathrm{Lc}}-\mathrm{V} 617 \mathrm{R}$ did not induce the clustering of EGFP-LC3 in HEK293 cells (Fig. 2B). Similarly, Lcmediated cell death was not observed in any of the cells expressing GluD2 ${ }^{\mathrm{Lc}}-\mathrm{V} 617 \mathrm{R}$ at 15,24 , or $36 \mathrm{~h}$ after transfection (Fig. 2C). These results indicated that constitutive ion flow is required for $\mathrm{GluD} 2{ }^{\mathrm{Lc}}$ to induce autophagy and cell death in an in vitro $L c$ model.

To further examine the contribution of cation influx to Lc-mediated autophagy and cell death, we next varied the concentrations of $\mathrm{Na}^{+}$in extracellular solutions of HEK293 cells expressing GluD2 ${ }^{\mathrm{Lc}}$ or GluD2 ${ }^{\text {wt }}$. When the extracellular $\mathrm{Na}^{+}$ concentration was decreased by replacing $\mathrm{Na}^{+}$with $\mathrm{N}$-methyl-D-glucosamine ${ }^{+}$ $\left(\mathrm{NMDG}^{+}\right)$, which is a large molecule that cannot penetrate $\mathrm{GluD} 2^{\mathrm{Lc}}$ channels, the number of EGFP-LC3 clusters in HEK293 cells expressing GluD2 ${ }^{\mathrm{Lc}}$ decreased when more $\mathrm{NMDG}^{+}$was used to replace $\mathrm{Na}^{+}$ and became similar to the number in cells expressing GluD2 ${ }^{\text {wt }}$ or mock (Fig. 2D). Similarly, the number of surviving cells increased proportionally (Fig. 2E). We also examined the effect of extracellular $\mathrm{Ca}^{2+}$ concentrations by incubating cells expressing GluD2 $2^{\mathrm{Lc}}$ in extracellular solutions containing 2, 5 , or $10 \mathrm{mM}$ of $\mathrm{Ca}^{2+}$; lower or higher $\mathrm{Ca}^{2+}$ concentrations were not used to prevent nonspecific cell death. Within this range of $\mathrm{Ca}^{2+}$ concentrations, the numbers of EGFP-LC3 clusters and the percentages of surviving cells did not change significantly (Fig. $2 D, E$ ). Together, these results suggest that Lc-induced autophagy and cell death were mainly dependent on currents carried by $\mathrm{Na}^{+}$, but not by $\mathrm{Ca}^{2+}$, in an in vitro $L c$ model.

\section{Constitutive ion flux is sufficient for Lc-mediated autophagy and cell death}

According to the "autophagic cell death" model, $L c$ mutation activates the n-PIST-Beclin1 pathway through the $\mathrm{C}$ terminus of GluD2 (Yue et al., 2002; Selimi et al., 2003). Thus, to directly examine the involvement of this pathway, we prepared GluD2 ${ }^{\text {wt }}$ $\Delta \mathrm{CT} 7$ and $\mathrm{GluD} 2{ }^{\mathrm{Lc}}-\Delta \mathrm{CT} 7$, which lacked the $\mathrm{C}$-terminal 7 amino acids essential for binding to n-PIST (Fig. 3A). If the release of $\mathrm{n}$-PIST from the $\mathrm{C}$ terminus of GluD2 ${ }^{\mathrm{Lc}}$ induces autophagy, the
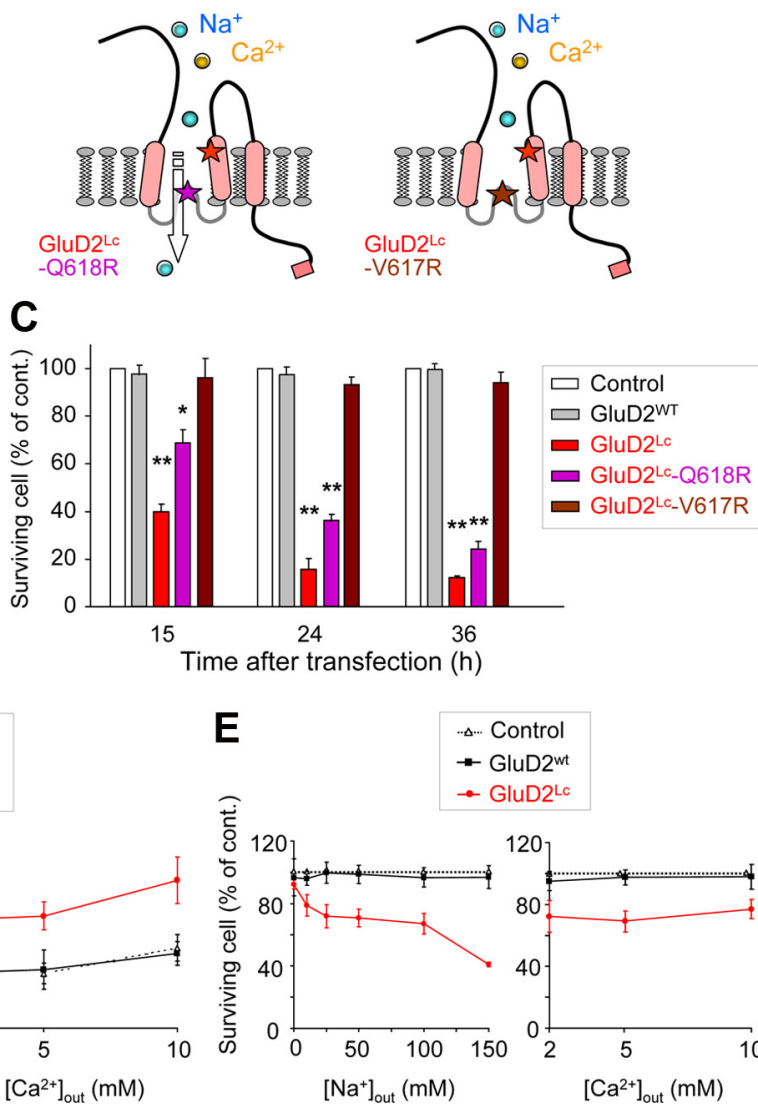

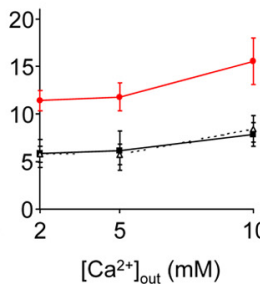

Figure 2. $\mathrm{Na}^{+}$influx, but not $\mathrm{Ca}^{2+}$, was necessary for Lc-mediated autophagy and cell death in HEK293 cells. $A$, Schematic diagrams of GluD2 ${ }^{\mathrm{Lc}}$ and its channel-pore mutants. GluD2 ${ }^{\mathrm{Lc}}-\mathrm{Q} 618 \mathrm{R}$, in which arginine (R) was substituted for $\mathrm{Q}$ at the $\mathrm{Q} / \mathrm{R}$ site, was mpermeable to $\mathrm{Ca}^{2+}$. GluD2 ${ }^{\mathrm{Lc}}-\mathrm{V} 617 \mathrm{R}$, in which $\mathrm{R}$ was substituted for valine $(\mathrm{V})$ at one position upstream of the $\mathrm{Q} / \mathrm{R}$ site, ansertion, the number of EGFP-LC3 puncta, as a marker for autophagosomes, was counted in each cell expressing mock , GluD2 ${ }^{\mathrm{LC}}$, GluD2 ${ }^{\mathrm{LC}}$-Q618R, or GluD2 ${ }^{\mathrm{LC}}$-V617R using the object detection algorithm. Error bars indicate the formation and cell death on extracellular $\mathrm{Na}^{+}$and $\mathrm{Ca}^{2+}$ concentrations. At $6 \mathrm{~h}$ after transfection, the culture medium was changed to artificial CSF containing various $\mathrm{Na}^{+}$and $\mathrm{Ca}^{2+}$ concentrations. At $15 \mathrm{~h}$ after transfection, the numbers of EGFP-LC3 clusters $(\boldsymbol{D})$ and surviving cells $(\boldsymbol{E})$ were counted, as described above. Each point represents the mean \pm SEM from three independent experiments. ${ }^{*} p<0.05 ;{ }^{* *} p<0.01$.

expression of GluD2 ${ }^{\text {wt }}-\Delta \mathrm{CT} 7$ would activate autophagy. However, the expression of GluD2 ${ }^{\mathrm{wt}}$ - $\Delta \mathrm{CT} 7 \mathrm{did}$ not induce any EGFPLC3 clustering or cell death in HEK293 cells (Fig. 3B,C). Similarly, GluD2-null mice that expressed the GluD2 ${ }^{\text {wt }}-\Delta C T 7$ transgene and those that expressed the GluD2 ${ }^{\mathrm{wt}}$ transgene displayed similar number of surviving Purkinje cells in vivo (supplemental Fig. 3, available at www.jneurosci.org as supplemental material). Furthermore, cells expressing GluD2 $2^{\mathrm{Lc}}-\Delta \mathrm{CT} 7$ (Fig. $3 B, C$ ) and cells expressing GluD2 ${ }^{\mathrm{Lc}}$ (Fig. $2 B, C$ ) showed similar levels of cell death and autophagy. These results indicated that whether $\mathrm{n}$-PIST binds to the $\mathrm{C}$ terminus of GluD2 or GluD2 ${ }^{\mathrm{Lc}}$ does not affect autophagy and cell death in vitro and in vivo.

The GluK2 (GluR6) subunit of kainate receptors becomes constitutively open when an $L c$-like mutation is introduced to the corresponding region (GluK2 ${ }^{\mathrm{LC}}$ ) (Kohda et al., 2000). The expression of GluK2 or GluK2 ${ }^{\text {Lc }}$ does not activate the n-PISTBeclin1 pathway because the $\mathrm{C}$ terminus of GluK2 does not bind to n-PIST (Fig. 3A). However, the expression of GluK2 ${ }^{\mathrm{Lc}}$, but not of GluK2 $2^{\text {wt }}$, induced EGFP-LC3 clustering and cell death in HEK293 cells (Fig. 3 B,C). Together, these results indicated that 
A

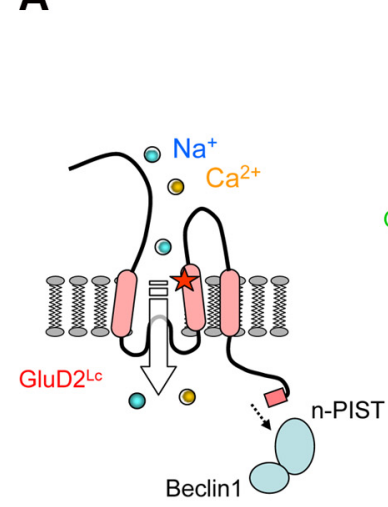

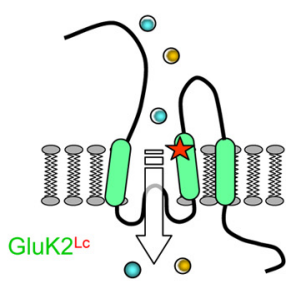

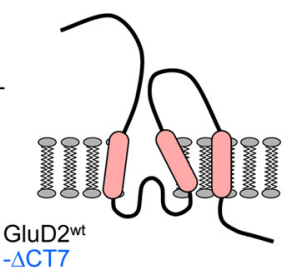

C
B

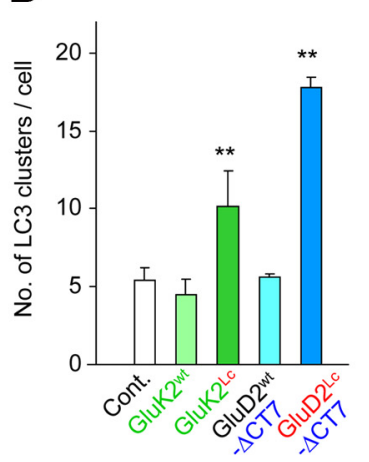

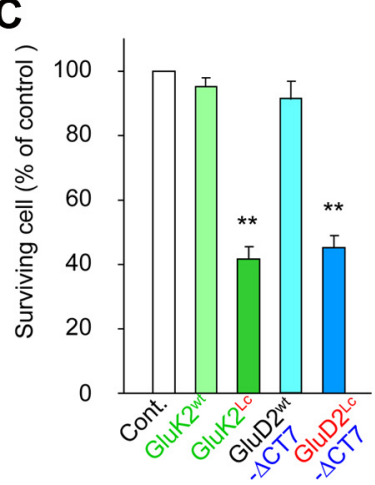

Figure 3. Binding to $n$-PIST-Beclin1 is dispensable for Lc-mediated autophagy and cell death. $A$, Schematic diagrams of various receptors that do not associate with n-PIST-Beclin1. The pink box at the C-terminal end of GluD2 ${ }^{\mathrm{LC}}$ indicates the C-terminal PDZ ligand region, which associates with Beclin1 via n-PIST. The GluK2 subunit of kainate receptors became constitutively open when the LC-like mutation was introduced to the corresponding region (GluK2 ${ }^{\mathrm{Lc}}$ ). Both wild-type GluK2 (GluK2 ${ }^{\mathrm{wt}}$ ) and GluK2Lc did not associate with n-PIST-Beclin1. Similarly, GluD2 ${ }^{\mathrm{wt}}-\Delta$ CT7 and GluD2 ${ }^{\mathrm{Lc}}-\Delta$ CT7 lacked the C-terminal 7 amino acids essential for binding to n-PIST-Beclin1. B, The C-terminal domain of GluD2 was not required for autophagy. HEK293 cells were cotransfected with CDNAs encoding EGFP-LC3 and mock (Cont.), GluK2 ${ }^{\text {wt }}$, GluK2 ${ }^{\mathrm{Lc}}$, GluD2 ${ }^{\mathrm{wt}}-\Delta$ CT7, or GluD2 ${ }^{\mathrm{Lc}}-\Delta$ CT7. At $15 \mathrm{~h}$ after transfection, the number of EGFP-LC3 puncta was counted in each cell. Error bars indicate the mean + SEM (from at least 60 cells in 3 independent experiments). C, The C-terminal domain of GluD2 was not required for cell death. HEK293 cells were cotransfected with CDNAs encoding EGFP and mock (Cont.), GluK2 ${ }^{\mathrm{wt}}$, GluK2 ${ }^{\mathrm{Lc}}$, GluD2 ${ }^{\mathrm{wt}}-\Delta \mathrm{CT7}$, or GluD2 ${ }^{\mathrm{Lc}}-\Delta \mathrm{CT} 7$. At $15 \mathrm{~h}$ after transfection, the number of EGFP-positive cells was counted and normalized by that in control cells (Cont.; mock transfected). Error bars indicate the mean + SEM (from 3 independent experiments). ${ }^{* *} p<0.01$.

constitutive currents were sufficient to induce autophagy and cell death, regardless of the n-PIST-Beclin1 pathway.

\section{Increased intracellular $\mathrm{Ca}^{2+}$ levels are not necessary for autophagy and cell death}

Excitotoxicity in neurons is tightly associated with activation of various $\mathrm{Ca}^{2+}$-dependent pathways because of a rapid influx of $\mathrm{Ca}^{2+}$ through voltage-gated $\mathrm{Ca}^{2+}$ channels and $\mathrm{Ca}^{2+}$-permeable glutamate receptors (Slemmer et al., 2005). Although these channels are not highly expressed in HEK293 cells (Bangalore et al., 1996), and Lc-mediated autophagy and cell death were mainly dependent on $\mathrm{Na}^{+}$influx (Fig. 2), elevated intracellular $\mathrm{Na}^{+}$ concentrations could indirectly increase $\mathrm{Ca}^{2+}$ levels by the reverse operation of plasma membrane $\mathrm{Na}^{+} / \mathrm{Ca}^{2+}$ exchanger. Thus, to determine whether intracellular $\mathrm{Ca}^{2+}$ accumulation is involved in Lc-mediated autophagy and cell death, we examined the changes in intracellular $\mathrm{Ca}^{2+}$ levels in HEK293 cells expressing GluD2 ${ }^{\mathrm{wt}}$, GluD2 ${ }^{\mathrm{Lc}}$, or GluD2 ${ }^{\mathrm{Lc}}-\mathrm{Q} 618 \mathrm{R}$ at 9,15 , and $24 \mathrm{~h}$ after transfection using the $\mathrm{Ca}^{2+}$-sensitive dye fura-2. Cells expressing GluD2 ${ }^{\mathrm{Lc}}$ showed significantly increased intracellular $\mathrm{Ca}^{2+}$ levels

at each time point as early as $9 \mathrm{~h}$ after transfection (Fig. 4A,B). The $\mathrm{Ca}^{2+}$ levels in cells expressing GluD2 ${ }^{\mathrm{Lc}}-\mathrm{Q} 618 \mathrm{R}$ were similar to those in cells expressing GluD2 ${ }^{\text {wt }}$ or mock at all time points (Fig. $4 A, B$ ), confirming that the $\mathrm{Ca}^{2+}$ permeability of GluD2 ${ }^{\mathrm{Lc}}$ was disrupted by the Q618R mutation. Since GluD2 ${ }^{\mathrm{Lc}}-\mathrm{Q} 618 \mathrm{R}$ induced cell death and autophagy (Fig. $2 A, B$ ), increased $\mathrm{Ca}^{2+}$ levels were not a prerequisite for Lc-mediated autophagy and cell death, at least in the in vitro heterologous cell model.

\section{Lc-mediated cell death is accompanied by decreased intracellular ATP levels and cell swelling}

How can constitutive $\mathrm{Na}^{+}$influx induce autophagy and cell death? Since $50 \%$ of the total energy production of the brain is consumed by $\mathrm{Na}^{+}-\mathrm{K}^{+}$ATPase to maintain $\mathrm{Na}^{+}$homeostasis under physiological conditions (Ames, 2000), we hypothesized that intracellular ATP levels would be decreased in cells suffering from $\mathrm{GluD} 2^{\mathrm{LC}}$ induced constitutive $\mathrm{Na}^{+}$influx. Autophagy is known to be regulated by AMPK (Meijer and Codogno, 2007), which is activated by the phosphorylation of its catalytic $\alpha$-subunit at Thr172 in response to an elevated intracellular AMP/ATP ratio (Carling, 2004). Immunoblot analyses using anti-AMPK $\alpha$ antibody and antiphospho-Thr172 antibody revealed that AMPK $\alpha$ was more significantly phosphorylated in cells expressing GluD2 ${ }^{\mathrm{Lc}}$ than in cells expressing GluD2 ${ }^{\text {wt }}$ (Fig. $5 A, B)$. Similarly, immunoblot analyses indicated that the ratio of LC3-II (lipidated) to LC3-I (cytosolic), a reliable marker for the induction of autophagy (Kabeya et al., 2004), was significantly higher in cells expressing GluD2 ${ }^{\mathrm{LC}}$ than in cells expressing GluD2 ${ }^{\mathrm{wt}}$ (Fig. $5 A, B$ ). Interestingly, the increased AMPK $\alpha$ phosphorylation level was detected as early as $9 \mathrm{~h}$ after the transfection of GluD2 ${ }^{\mathrm{Lc}}$, before increased LC3-II levels were observed at $15 \mathrm{~h}$. We also found that the reduction of ATP levels in cells expressing GluD2 ${ }^{\mathrm{Lc}}$ was proportionally prevented by replacing the increasing concentrations of extracellular $\mathrm{Na}^{+}$with $\mathrm{NMDG}^{+}$(supplemental Fig. 2, available at www.jneurosci.org as supplemental material). These results support the hypothesis that the expression of GluD2 ${ }^{\mathrm{Lc}}$ decreased the intracellular ATP level, possibly by the overactivation of $\mathrm{Na}^{+}-\mathrm{K}^{+}$ATPase, thereby inducing autophagy via AMPK activation.

To examine the role of AMPK activation in Lc-mediated autophagy and cell death, we inhibited AMPK by expressing its two dominant-negative AMPK mutants (AMPK $\alpha 1 D N$ and AMPK $\alpha 2 \mathrm{DN}$ ); the $\alpha$ subunit is encoded by the two genes $\alpha 1$ and $\alpha 2$ (Long and Zierath, 2006), and the suppression of either the $\alpha 1$ or the $\alpha 2$ subunit was not sufficient to block AMPK activity (data not shown), as reported previously (Viollet et al., 2003). Immunoblot analyses indicated that the increased LC3-II/LC3-I ratio observed in cells expressing $\mathrm{GluD} 2{ }^{\mathrm{LC}}$ was significantly suppressed 
by the coexpression of AMPK $\alpha 1 \mathrm{DN}$ and AMPK $\alpha 2 \mathrm{DN}$; the ratio became similar to that in cells expressing GluD2 ${ }^{\mathrm{wt}}$ (Fig. $5 C, D)$. Nevertheless, Lc-induced cell death was not prevented by the coexpression of AMPK $\alpha 1 \mathrm{DN}$ and AMPK $\alpha 2 \mathrm{DN}$ (Fig. $5 E$ ). These results suggest that although Lcmediated autophagy was likely regulated by the AMPK pathway, Lc-induced cell death was not directly caused by autophagy.

Necrosis is generally the end result of bioenergetic catastrophe resulting from ATP depletion (Edinger and Thompson, 2004). Since necrotic cell death is known to be associated with persistent cell swelling, known as necrotic volume increase (Barros et al., 2001), we examined the morphological changes of HEK293 cells expressing GluD2 ${ }^{\mathrm{Lc}}$. More than half of HEK293 cells expressing GluD2 ${ }^{\mathrm{Lc}}$ had been markedly swollen by $15 \mathrm{~h}$ when cell death was observed (supplemental Fig. 5, available at www.jneurosci.org as supplemental material). Averaged areas occupied by single cells were $105.7 \pm 1.9$ pixels for mock-transfected cells and $130.8 \pm$ 4.4 pixels for GluD2 ${ }^{\mathrm{Lc}}$-expressing cells (mean \pm SEM; $p<0.001 ; n>20$ cells). At 6 to $14 \mathrm{~h}$ after transfection, some cells were also associated with plasma membrane rupture, a morphological characteristic of the necrotic cell death (supplemental Movie 1, available at www.jneurosci.org as supplemental material). These results suggest that cell death was likely caused by necrosis in this in vitro $L c$ model.

\section{GluD2 ${ }^{\text {Lc }}$-mediated cell death and autophagy in neurons}

Does GluD2 ${ }^{\mathrm{Lc}}$ induce autophagy and death in neurons in the same manner as observed in heterologous cells? First, we examined the effect of the expression of GluD2 ${ }^{\mathrm{Lc}}$ and its various mutants in dissociated hippocampal neurons in vitro. Cultured hippocampal neurons were cotransfected with plasmids encoding mCherry, EGFP-LC3, and each GluD2 variant at 12 DIV. Neurons expressing GluD2 ${ }^{\mathrm{Lc}}$, GluD2 ${ }^{\mathrm{Lc}}-\mathrm{Q} 618 \mathrm{R}$, or GluD2 ${ }^{\mathrm{Lc}}$ $\triangle \mathrm{CT} 7$ showed a punctate pattern of EGFP-LC3 within their cell bodies at $15 \mathrm{~h}$ after transfection (Fig. 6A). In addition, the percentage of mCherry-positive cells was significantly reduced when GluD2 ${ }^{\mathrm{Lc}}$, GluD2 ${ }^{\mathrm{Lc}}$-Q618R, or GluD2 ${ }^{\mathrm{Lc}}-\Delta \mathrm{CT} 7$ was coexpressed in neurons, indicating that many neurons had died by $15 \mathrm{~h}$ after transfection (Fig. $6 \mathrm{~B}$ ). In contrast, the expression of GluD2 ${ }^{\text {wt }}$, GluD2 ${ }^{\mathrm{Lc}}-\mathrm{V} 617 \mathrm{R}$, or GluD2 ${ }^{\text {wt }}-\Delta$ CT7 did not induce the clustering of EGFP-LC3 or cell death (Fig. 6A,B). These results were consistent with those obtained in heterologous cells (Figs. 1-3), suggesting that Lc-
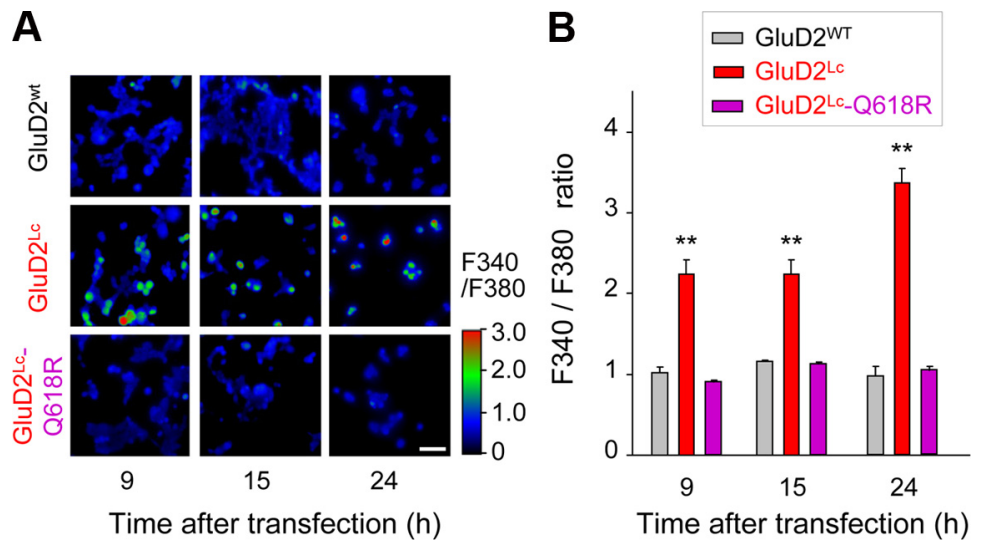

Figure 4. Intracellular $\mathrm{Ca}^{2+}$ levels were not elevated in cells expressing GluD2 ${ }^{\mathrm{LC}}$-0618R. $\boldsymbol{A}$, Representative pseudocolorimages of cells loaded with fura-2. HEK293 cells expressing GluD2 ${ }^{\text {wt }}$, GluD2 ${ }^{\mathrm{Lc}}$, or GluD2 ${ }^{\mathrm{Lc}}-0618 \mathrm{R}$ were loaded with fura-2 at the indicated time after transfection. The ratio of the fluorescence intensity excited at $340 \mathrm{~nm}$ (F340) to that excited at 380 (F380) was shown in pseudocolor; high $\mathrm{Ca}^{2+}$ levels are shown in red, and low $\mathrm{Ca}^{2+}$ levels are shown in blue. B, Intracellular $\mathrm{Ca}^{2+}$ levels are elevated in cells expressing GluD2 ${ }^{\mathrm{Lc}}$, but not in cells expressing GluD2 ${ }^{\text {wt }}$ or GluD2 ${ }^{\mathrm{Lc}}$-Q618R. Error bars represent the mean F340/F380 ratio + SEM ( $n>60$ cells from 3 independent experiments). Note that cells expressing GluD2 ${ }^{\mathrm{Lc}}-\mathrm{Q} 618 \mathrm{R}$ did not show increased intracellular $\mathrm{Ca}^{2+}$ levels at any time point, but all these cells eventually died (Fig. 2). Scale bar, $100 \mu \mathrm{m} .{ }^{* *} p<0.01$.

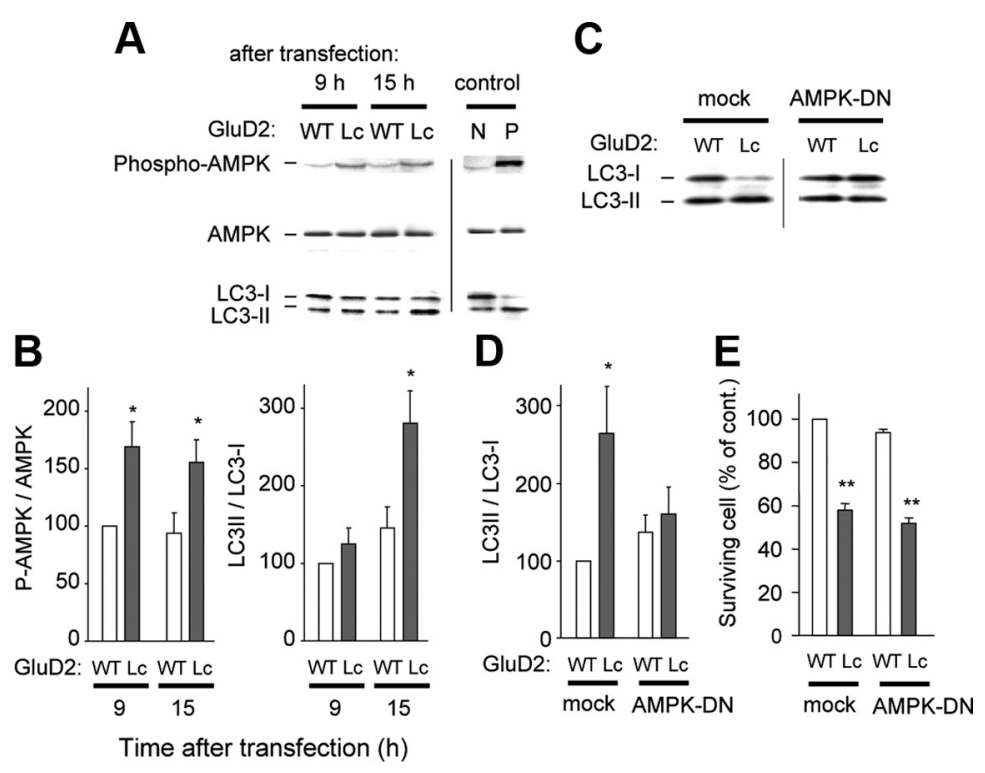

Figure 5. Phosphorylation of AMPK mediates autophagy induced by $\mathrm{GluD2}^{\mathrm{Lc}}$. $\boldsymbol{A}, \boldsymbol{B}$, Immunoblot analysis of the phosphorylation of AMPK. HEK293 cells expressing GluD2 ${ }^{\text {wt }}$ [wild type (WT)] or GluD2 ${ }^{\mathrm{Lc}}$ (LC) were collected at the indicated time after transfection and were subjected to an immunoblot analysis using anti-AMPK $\alpha$, anti-phospho-Thr172, and anti-LC3 antibodies. The phosphorylated form of AMPK was increased in cells expressing GluD2 ${ }^{\mathrm{Lc}}$ at $9 \mathrm{~h}$ after transfection before the detection of an increase in the LC3-II level at $15 \mathrm{~h}$. Nontransfected cells were used as a negative control (N). Cells treated with $5 \mu \mathrm{g} / \mathrm{ml}$ of oligomycin and serum starvation were used as a positive control (P). B, Quantitative analysis of immunoblot assay. The mean band intensity ratios of phospho-AMPK to AMPK (left panel) and of LC3-II to LC3-I (right panel) from cells expressing GluD2 ${ }^{\text {wt }}$ at $9 \mathrm{~h}$ were established as 100\%. Error bars represent the mean + SEM (from at least 6 independent experiments). C, D, Expression of dominant-negative AMPK inhibited GluD2 ${ }^{\text {Lc}}$-induced autophagy. HEK293 cells coexpressing dominant-negative AMPK (AMPKDN) and GluD2 ${ }^{\text {wt }}$ or GluD2 ${ }^{\mathrm{Lc}}$ were subjected to an immunoblot analysis using anti-LC3 antibody. The mean band intensity ratio of LC3-II to LC3-I from cells coexpressing mock CDNA and GluD2 ${ }^{\text {wt }}$ was established as $100 \%$ (D). Error bars represent the mean + SEM (from 6 independent experiments). $\boldsymbol{E}$, Expression of dominant-negative AMPK did not rescue GluD2 ${ }^{\text {Lc }}$-induced cell death. HEK293 cells were cotransfected with cDNAs encoding EGFP, AMPK-DN (or mock), and GluD2 ${ }^{\text {wt }}$ (or GluD2 ${ }^{\mathrm{Lc}}$ ). At $15 \mathrm{~h}$ after transfection, the number of EGFP-positive cells was counted and normalized by that in cells expressing EGFP, mock, and GluD2 ${ }^{\text {wt }}$. Error bars indicate the mean + SEM (from 3 independent experiments). ${ }^{*} p<0.05 ;{ }^{* *} p<0.01$.

induced autophagy and cell death were also caused by ion overload, not the n-PIST-Beclin 1 pathway, in cultured neurons.

Focal swelling of axons has been reported as early signs of Purkinje cell death in $L c$ (Wang et al., 2006) and other neurodegenerative disorders (Coleman, 2005). Thus, we examined the 


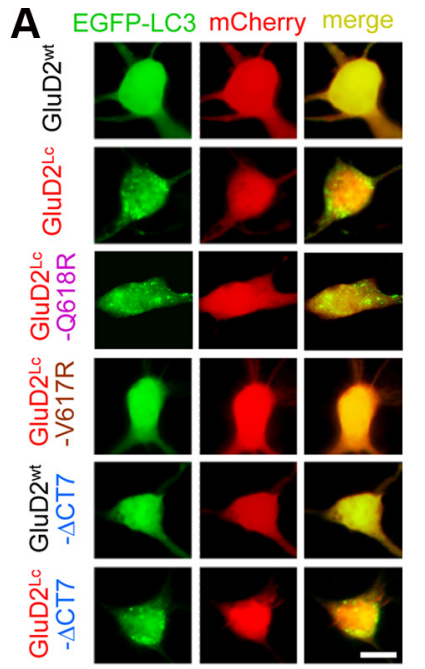

B

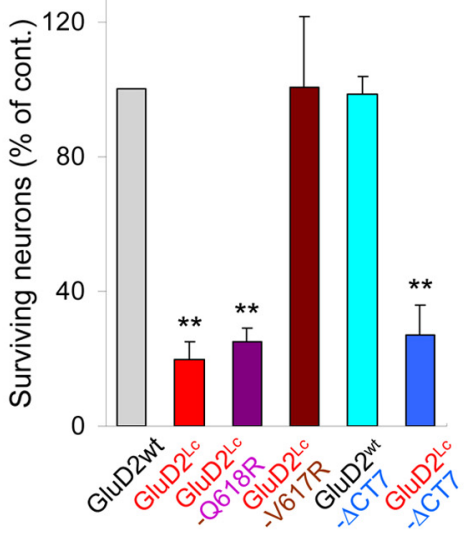

C
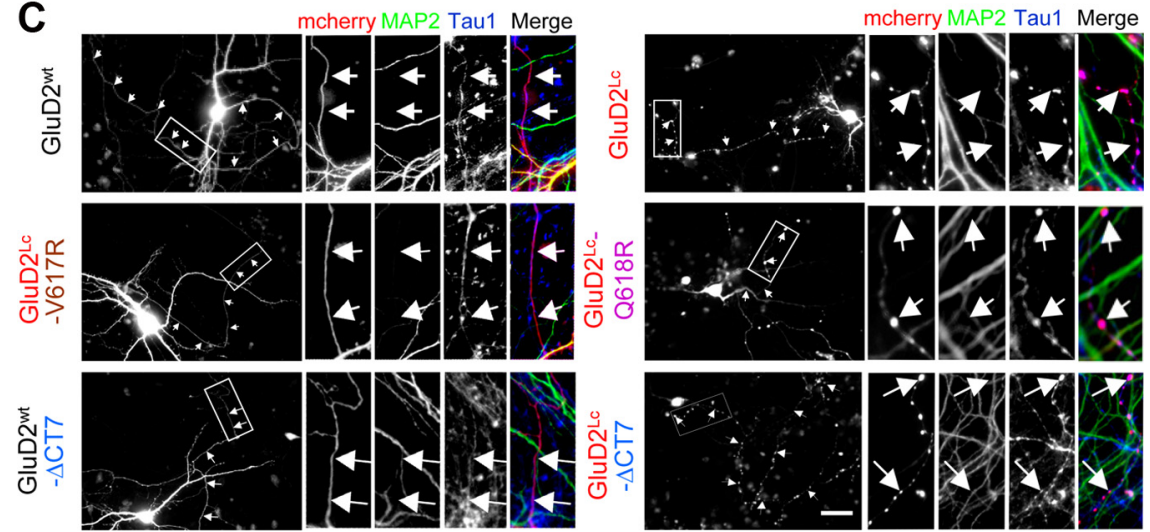

Figure 6. Induction of autophagy, axonal degeneration, and cell death in neurons by GluD2 ${ }^{\mathrm{Lc}}$ and various mutants. $\boldsymbol{A}$, Representative fluorescent images of EGFP-LC3 and mCherry in neurons. Cultured hippocampal neurons at 12 DIV were transfected with cDNAs encoding EGFP-LC3, mCherry, and one of GluD2 ${ }^{\text {wt }}$, GluD2 ${ }^{\mathrm{Lc}}$, GluD2 ${ }^{\mathrm{Lc}}-0618 \mathrm{R}$, GluD2 ${ }^{\mathrm{Lc}}-$ V617R, GluD2 ${ }^{\text {wt }}-\Delta$ CT7, or GluD2 ${ }^{\mathrm{Lc}}$. $\Delta \mathrm{CT7}$ and then analyzed after $15 \mathrm{~h}$. Note that EGFP-LC3 clusters were observed in the cell bodies of neurons expressing GluD2 ${ }^{\mathrm{Lc}}$, GluD2 ${ }^{\mathrm{Lc}}-0618 \mathrm{R}$, or GluD2 ${ }^{\mathrm{Lc}}-\Delta \mathrm{CT7}$. B , Survival of neurons expressing GluD2 ${ }^{\mathrm{Lc}}$ and various mutants. At $15 \mathrm{~h}$ after transfection, the number of mCherry-positive neurons was counted and normalized by that in neurons expressing GluD2 ${ }^{\text {wt }}$. Error bars indicate the mean + SEM (from 5 independent experiments). C, Representative fluorescent images of axons of hippocampal neurons expressing GluD2 ${ }^{\mathrm{Lc}}$, GluD2 ${ }^{\mathrm{Lc}}-\mathrm{Q} 618 \mathrm{R}$, or GluD2 ${ }^{\mathrm{Lc}}-\Delta \mathrm{CT} 7$. Cultured hippocampal neurons were transfected with cDNAs encoding mCherry and GluD2 ${ }^{\text {wt }}$ or GluD2 mutants as indicated, and then stained for the dendritic marker MAP2 (green) and the axonal marker tau-1 (blue). The regions indicated by the white boxes are enlarged in the right panels. Note that marked focal swellings were observed along the MAP2-negative and tau-1-positive axons of hippocampal neurons expressing GluD2 ${ }^{\mathrm{Lc}}$, GluD2 ${ }^{\mathrm{Lc}}-0618 \mathrm{R}$, and GluD2 ${ }^{\mathrm{Lc}}$ $\Delta C$ T7. White arrows and arrowheads indicate the axons. Scale bars: $A, 10 \mu \mathrm{m} ; \boldsymbol{C}, 100 \mu \mathrm{m}$. ${ }^{* *} p<0.01$.

morphology of neurites in hippocampal neurons expressing mCherry and each GluD2 mutant. A punctate pattern of mCherry was observed along neurites of neurons expressing GluD2 ${ }^{\mathrm{Lc}}$, GluD2 ${ }^{\mathrm{Lc}}-\mathrm{Q} 618 \mathrm{R}$, or GluD2 ${ }^{\mathrm{Lc}}-\Delta \mathrm{CT} 7$, but not those expressing GluD2 ${ }^{\mathrm{wt}}$, GluD2 ${ }^{\mathrm{wt}}-\Delta \mathrm{CT} 7$, or GluD2 ${ }^{\mathrm{Lc}}-\mathrm{V} 617 \mathrm{R}$ (Fig. $6 C)$. Immunostaining of axons using an axonal marker, tau-1, and a dendritic marker, microtubule-associated protein 2, revealed that axons of hippocampal neurons expressing GluD2 ${ }^{\mathrm{Lc}}$, GluD2 ${ }^{\mathrm{Lc}}$-Q618R, or GluD2 ${ }^{\mathrm{Lc}}-\Delta \mathrm{CT} 7$ showed severe fragmentation with a series of bead-like varicosities and focal swellings (Fig. $6 C)$. These results indicate that ion overload by expressing GluD2 ${ }^{\text {Lc }}$ caused not only cell death, but also axon swelling, a characteristic feature of $L c$ Purkinje cells.

Lc-mediated cell death is not rescued by the lack of autophagy in vivo

Finally, to examine the role of autophagy in Lc-mediated cell death in vivo, we crossed Lc mice with conditional Atg5 knock- out mice (Atg5 $5^{\text {flox/flox; }}$ pcp2-Cre), in which Atg5, a gene indispensable for autophagy, was selectively excised in cerebellar Purkinje cells as early as P6 and was fully established by P21 (Nishiyama et al., 2007). Although basal autophagy is necessary for physiological functions of neurons (Hara et al., 2006; Komatsu et al., 2006), Purkinje cells remain normal until 8 weeks after birth in Atg $5^{\text {flox/flox; }}$ pcp2Cre mice (Nishiyama et al., 2007). We found that like $L c /+$ mice, $L c /+$ mice on an Atg5 $5^{\text {flox/flox; }}$ pcp2-Cre background showed a prominent ataxic gait (Fig. 7A; supplemental Movie 2, available at www. jneurosci.org as supplemental material) at P21. At P10, some Purkinje cells were already similarly lost in $L c /+$ cerebellum both on wild-type and Atg5-null backgrounds (Fig. 7C; supplemental Fig. 4, available at www.jneurosci.org as supplemental material). Interestingly, at P21, Purkinje cells were significantly fewer in $\mathrm{Lc} /+$ mice on an Atg5-null background than in $L c /+$ mice (Fig. $7 B, C$ ). These results suggest that Lc-mediated cell death was not directly caused by autophagy activation either in vivo or in vitro; rather, autophagy may have protective roles against Lc-mediated neurodegeneration in vivo.

We next examined the morphology of Purkinje-cell axons, which make synapses with neurons in the DCNs, by immunohistochemical analyses using antibodies against calbindin, a Purkinje-cell marker, and synaptophysin, an axon terminal marker. At P21, the degree of axon swellings, which was quantified by measuring the total area that stained double-immunopositive for calbindin and synaptophysin in the DCN region, was similar between $\mathrm{Lcl}+$ mice on an Atg5 $5^{\text {flox/flox; }}$ pcp2-Cre background and $L c /+$ mice (Fig. 7D). Interestingly, at P10, mild axonal swelling of Purkinje cells was observed in $L c /+$ mice, but not in $L c /+$ mice on an Atg $5^{\text {flox/flox; }}$ pcp2-Cre background (Fig. $7 B, D$; supplemental Fig. 4, available at www.jneurosci.org as supplemental material). These results suggest that although autophagy is not involved in Lc cell death, it may partly contribute to the axonal swelling of $L c /+$ Purkinje cells at early stages (see Discussion).

Finally, to further define the $L c$ cell death in vivo, we examined calpain-mediated proteolysis, which is often associated with necrotic neuronal death in ischemic and excitotoxic injury (Wang, 2000). Unlike HEK293 cells, neurons are equipped with various voltage-gated $\mathrm{Ca}^{2+}$ channels, and thus $\mathrm{Na}^{+}$-induced depolarization through GluD2 ${ }^{\mathrm{Lc}}$ is likely followed by $\mathrm{Ca}^{2+}$ influx through these channels and activation of various $\mathrm{Ca}^{2+}$-dependent degradative enzymes, including calpains (Slemmer et al., 2005). Immunohistochemical analysis using an antibody against the 136 $\mathrm{kDa}$ fragment of $\alpha$-spectrin cleaved by calpain (136 kf-spectrin) (Takano et al., 2005) detected specific immunoreactivity in $L c /+$, but not in wild-type, Purkinje cells at P14 (Fig. 8A). Indeed, 
the immunoblot analyses using the anti$136 \mathrm{kf}$-spectrin antibody showed that $\alpha$-spectrin was cleaved into a $136 \mathrm{kDa}$ fragment in $\mathrm{Lcl}+$ cerebellum (Fig. $8 \mathrm{~B}$ ). These results indicate that calpaindependent structural breakdown is involved in $L c /+$ cerebellum and support the hypothesis that $L c$ cell death was caused by necrosis in vivo.

\section{Discussion}

Although a point mutation in GluD2 has been identified as the cause of neurodegeneration in $L c$ mice, the mechanisms by which $L c$ Purkinje cells die have remained elusive. Here, we reinvestigated Lc-mediated cell death in vitro and in vivo, focusing on the autophagic cell death hypothesis.

\section{Activation of autophagy by ion overload}

We demonstrated that when the $\mathrm{Na}^{+}$flow through GluD2 ${ }^{\text {Lc }}$ channels was disrupted by the introduction of mutations into the channel pore domain (Figs. 2, 6) or by replacing the extracellular $\mathrm{Na}^{+}$ions with nonpermeable $\mathrm{NMDG}^{+}$(Fig. 2), GluD2 ${ }^{\mathrm{Lc}}$ no longer induced autophagy in HEK293 cells or cultured hippocampal neurons. Conversely, GluD2 $2^{\mathrm{Lc}}-\Delta \mathrm{CT} 7$ or GluK2 ${ }^{\mathrm{Lc}}$, which do not associate with n-PIST-Beclin 1 but allow constitutive ion influx, induced autophagy in HEK293 cells (Fig. 2) and cultured hippocampal neurons (Fig. 6). Therefore, constitutive currents were likely necessary and sufficient to induce autophagy, regardless of the n-PIST-Beclin1 pathway, at least in vitro.

Autophagy is an evolutionally conserved catabolic process through which macromolecules and ATP are regenerated from cytoplasmic components in response to nutrient starvation (Levine and Yuan, 2005). AMPK, a highly conserved sensor for intracellular ATP, is thought to induce autophagy in mammalian cells, as well as in yeast, by inhibiting mammalian target of rapamycin (mTOR) (Meijer and Codogno, 2007). We demonstrated that the expression of GluD ${ }^{\mathrm{Lc}}$ decreased intracellular ATP levels in a manner that was dependent on the extracellular $\mathrm{Na}^{+}$concentrations (supplemental Fig. 3, available at www. jneurosci.org as supplemental material) and activated AMPK before autophagy was activated (Fig. $5 A, B$ ). Furthermore, the expression of dominant-negative AMPK $\alpha$ prevented GluD2 ${ }^{\mathrm{Lc}}$ induced autophagy in heterologous cells (Fig. 5C,D). From these results, we propose that decreased ATP levels, which were probably caused by the overactivation of $\mathrm{Na}^{+}-\mathrm{K}^{+}$ATPase in response to constitutive $\mathrm{Na}^{+}$currents associated with GluD2 ${ }^{\mathrm{Lc}}$ channels, activate AMPK and autophagy (supplemental Fig. 6, available at www.jneurosci.org as supplemental material).

The accumulation of autophagosomes has been observed during the early stages of many neurodegenerative disease, such as Alzheimer's disease (Yu et al., 2005), prion disease (Sikorska et
B
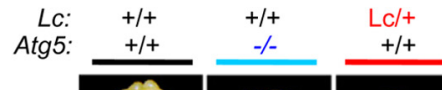

$\mathrm{LC} /+$
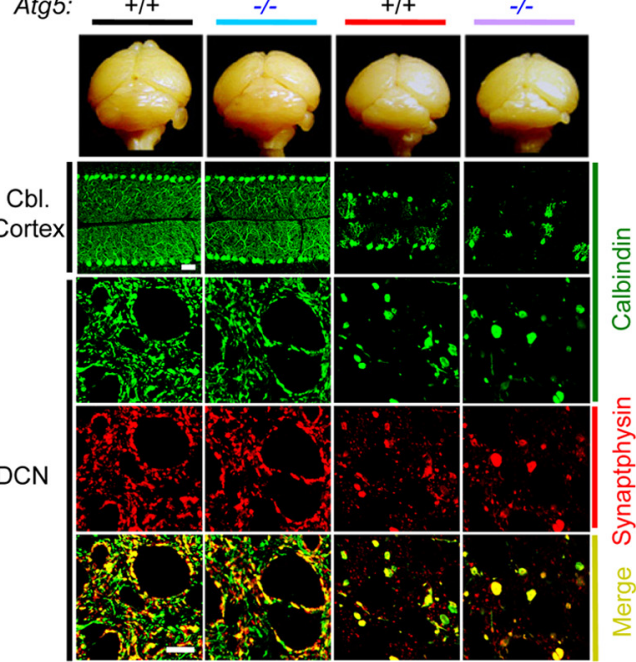

DCN
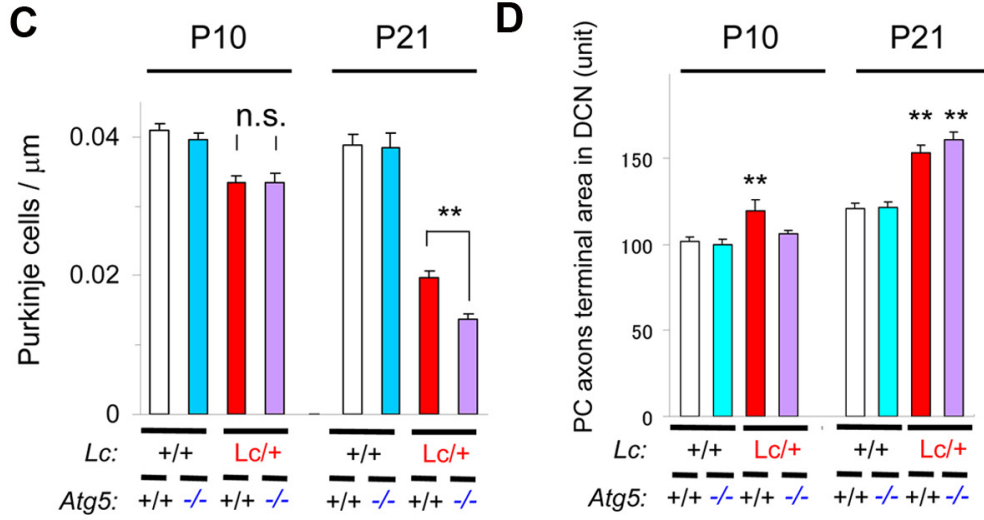

Figure 7. LC-mediated cell death was aggravated on an Atg5-null background in vivo. A, Abnormal footprint patterns of $L C /+$ mice on an Atg5-null background at P21. The gait patterns of $\mathrm{LCl}+;$ Atg $5^{\text {flox/flox }}$ mice (middle) were similarly ataxic to those of f $L C /+$ mice on an Atg5-null background at P21. Representative gross morphology (top panels) and immunohistochemical m m bottom panels, $100 \mu \mathrm{m}$. C Quantification of surviving Purkinje cells at P10 and P21. The number of Purkinje cells was allong the Purkinje cell layer in confocal optical sections. The values represent the mean + SEM from at least three slices antified by measuring the total area that stained double immunopositive for calbindin and synaptophysin in the DCN region. The values represent the mean + SEM from at least three slices from two animals. ${ }^{* *} p<0.01$. n. s., Not significant.

al., 2004), Parkinson's disease (Zhu et al., 2003), and Huntington's disease (Li et al., 2001). In addition, autophagosomes are reportedly accumulated in neurons after hypoxia-ischemia (Koike et al., 2008), brain injury (Diskin et al., 2005), and glutamate application (Borsello et al., 2003; Sadasivan et al., 2006). Nevertheless, how autophagosomes become accumulated in neurons has remained mostly unclear. Impaired clearance might contribute to the accumulation of autophagosomes in neurons (Boland et al., 2008); however, the clearance pathway was intact in $L c /+$ Purkinje cells (Wang et al., 2006). In addition, in $L c /+$ Purkinje cells, enlarged dystrophic mitochondria were frequently observed (Caddy and Biscoe, 1979; Dumesnil-Bousez and Sotelo, 1992) and mitochondrial cytochrome oxidase activity was significantly increased (Vogel et al., 2001), suggesting that mitochondrial oxidative respiration was increased in response to the increased demand for ATP in $L c /+$ Purkinje cells. Therefore, although autophagy could be triggered by several pathways, we postulate that AMPK activation in response to ion overload 


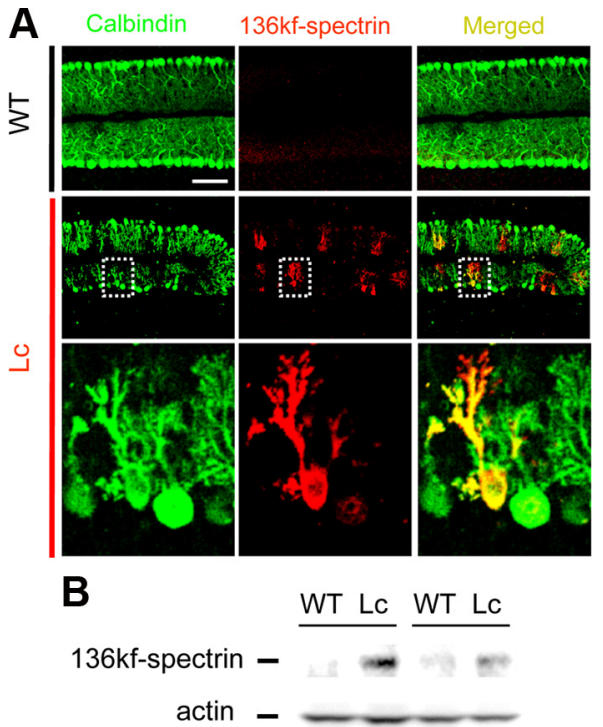

Figure 8. Cleavage of spectrin by calpains in $L c$ mice in vivo. $A$, Immunohistochemical studies. At P14, parasagittal sections of wild-type (WT) and Lc cerebellum were immunostained for calbindin (green) and $136 \mathrm{kDa}$ fragment of $\alpha$-spectrin cleaved by calpain ( $136 \mathrm{kf}$-spectrin; red). The regions indicated by the white boxes are enlarged in the bottom panels. Scale bar, $100 \mu \mathrm{m}$. $B$, Immunoblot analysis of $136 \mathrm{kf}$-spectrin. Cerebellar extracts from the WT and $L c$ mice at P14 were separated by SDS-PAGE, blotted onto polyvinyldene disulfide membrane, and subjected to an immunoblot analysis using anti-136 kf-spectrin and anti-actin antibodies. Two independent samples for each genotype were analyzed.

might be a major pathway in the activation of autophagy in $\mathrm{Lc} /+$ mice and, possibly, in other neurodegenerative disorders.

The theory that autophagy was induced by the n-PIST-Beclin 1 pathway in $L c /+$ mice was based on two major findings. First, the coexpression of Beclin1 with n-PIST, but not with n-PIST lacking the PDZ domain, induced autophagosome formation in heterologous cells (Yue et al., 2002). However, because GluD2 ${ }^{\mathrm{Lc}}$ was not coexpressed in this assay, whether n-PIST-Beclin 1 was released from or activated by GluD2 ${ }^{\mathrm{Lc}}$ was unclear. Second, $L c /$ ho Purkinje cells, which were less depolarized at P5, showed more autophagosomes than $L c /+$ Purkinje cells (Selimi et al., 2003). The reason for this phenomenon is unclear, but Lc/ho Purkinje cells might have displayed early constitutive currents, which caused autophagy and cell death before the membrane potentials were measured in the remaining healthier cells at $\mathrm{P} 5$. Indeed, when the same amount of cDNA encoding GluD2 ${ }^{\mathrm{Lc}}$ was used, HEK293 cells transfected with GluD2 ${ }^{\mathrm{Lc}}$ alone (which mimicked Lc/ho) showed a larger leak current than those transfected with GluD2 ${ }^{\mathrm{Lc}}$ and GluD2 ${ }^{\text {wt }}$ (which mimicked $L c /+$ ) (Kohda et al., 2000). In addition, n-PIST-Beclin1 is reportedly localized at the Golgi apparatus (Kihara et al., 2001; Hicks and Machamer, 2005) and interacts with Golgi-associated proteins, whereas GluD2 is efficiently transported to the cell surface (Yuzaki, 2008). Thus, although Beclin1 is intimately involved in autophagy in neurons, GluD2 ${ }^{\mathrm{Lc}}$ might not directly activate this pathway.

\section{Lc-mediated cell death}

The overexpression or deletion of the apoptosis-related genes $B c l-2$ or Bax, respectively, did not completely prevent the degeneration of $L c$ Purkinje cells (Vogel et al., 2006). In addition, apoptosis requires normal ATP levels, whereas the ATP levels were decreased in HEK293 cells expressing GluD2 ${ }^{\text {Lc }}$ (Fig. 5; supplemental Fig. 2, available at www.jneurosci.org as supplemental material) and possibly in Lc Purkinje cells (Vogel et al., 2006) Therefore, apoptosis is unlikely to be the main mechanism for Lc-mediated Purkinje cell death. On the other hand, the expression of dominant-negative $\mathrm{AMPK} \alpha$, although preventing autophagy activation, did not rescue GluD $2{ }^{\mathrm{Lc}}$-induced cell death (Fig. $5 C, D)$. Furthermore, the disruption of Atg5 in Purkinje cells did not prevent but rather enhanced cell death at P21 in $L c$ mice (Fig. 7). These results suggest that Lc-mediated cell death was not caused by excessive autophagy activation either in vivo or in vitro.

$\mathrm{GluD} 2^{\mathrm{Lc}}$-mediated cell death was prevented when ion flow through GluD2 ${ }^{\mathrm{Lc}}$ channels was disrupted in HEK293 cells and cultured hippocampal neurons (Figs. 2, 6). Very recently, a nonselective channel blocker, 1-naphthyl-acetyl spermine, was also shown to block $L c /+$ Purkinje cell death in cultured cerebellar slices (Zanjani et al., 2009). Conversely, GluD2 ${ }^{\mathrm{Lc}}-\Delta \mathrm{CT} 7$ or GluK2 ${ }^{\mathrm{Lc}}$ receptors, which allowed constitutive ion influx, induced cell death in HEK293 cells and cultured hippocampal neurons (Figs. 2, 6). Therefore, Lc-mediated cell death was likely caused by excitotoxicity, in which the glutamate receptors were overstimulated, resulting in excess ion influx.

Necrotic cell death is known to be associated with persistent cell swelling, known as necrotic volume increase (Barros et al., 2001). In addition, necrosis is generally the end result of bioenergetic catastrophe resulting from ATP depletion (Edinger and Thompson, 2004). Thus, swelling and decreased ATP levels in HEK293 cells expressing GluD2 ${ }^{\mathrm{LC}}$ are consistent with a hypothesis that Lc-mediated cell death was caused by necrosis. Furthermore, necrotic neuronal death caused by excitotoxicity with excessive ion flux is often associated with calcium overload and activation of calpains in neurons. Indeed, we observed calpaindependent specific proteolysis of $\alpha$-spectrin in $L c /+$ Purkinje cells (Fig. 8). Together, we suggest that Lc-mediated cell death, both in vitro and in vivo, likely represents necrosis resulting from ion overload through GluD2 ${ }^{\mathrm{Lc}}$ channels, accompanied with features of autophagy.

\section{Possible roles of autophagy in the $L c$ model}

If autophagy serves as a mechanism for boosting ATP levels in cells suffering from ion overload, the blockade of autophagy would likely aggravate cell death in $L c /+$ Purkinje cells. Indeed, the disruption of Atg5 in Purkinje cells significantly exacerbated Purkinje-cell death in $\mathrm{Lc} /+$ mice at P21 (Fig. $7 \mathrm{~B}, \mathrm{C}$ ), suggesting that autophagy plays a protective role against Lc-mediated cell death. In contrast, the blockade of autophagy by the expression of dominant-negative form of AMPK $\alpha$ did not aggravate GluD2 ${ }^{\mathrm{Lc}}$ induced cell death in HEK293 cells expressing GluD2 ${ }^{\text {Lc }}$ (Fig. 5). We postulate that autophagy activation might be insufficient or might act too slowly to prevent the rapidly progressing cell death caused by overexpression of GluD2 ${ }^{\mathrm{Lc}}$ in the in vitro model. Indeed, the activation of autophagy by the inhibition of mTOR reduced neurodegeneration in mouse models of Huntington's disease (Sarkar et al., 2007) and traumatic brain injury (Erlich et al., 2007). Therefore, $L c$ mice will continue to be a valuable model of excitotoxic neurodegeneration for development of a new therapeutic approach targeting the autophagic pathway.

Axon swelling is a hallmark of axonal dystrophy, which is observed in many neurodegenerative disorders associated with excitotoxicity (Coleman, 2005). Indeed, hippocampal neurons expressing constitutively active channels (i.e., GluD2 ${ }^{\mathrm{Lc}}, \mathrm{GluD} 2^{\mathrm{Lc}}$ Q618R, or GluD2 $\left.{ }^{\text {Lc }}-\Delta \mathrm{CT} 7\right)$ showed severe axon dystrophy (Fig. 6C). In addition, the disruption of Atg5 in $L c /+$ Purkinje cells did not prevent axonal swellings at P21 (Fig. $7 B, D$ ). These results 
indicate that axonal swellings in $L c$ mice were also caused by ion overload, not by the autophagic pathway.

It is unclear why the degree of axonal swellings was reduced in $\mathrm{Lcl}+$ Purkinje cells on an Atg5 $5^{\text {flox/flox }}$; pcp2-Cre background at P10 (Fig. 7D). Activation of the autophagic pathway in response to ion overload may have caused accumulation of autophagosomes and swelling in axons at early stages. Since axonal swellings are often observed during the early stages of various excitotoxic neurodegenerative disorders, additional studies are warranted to clarify the role of autophagy in axonal swelling and its pathological significance.

\section{References}

Ames A 3rd (2000) CNS energy metabolism as related to function. Brain Res Brain Res Rev 34:42-68.

Bangalore R, Mehrke G, Gingrich K, Hofmann F, Kass RS (1996) Influence of L-type Ca channel alpha 2/delta-subunit on ionic and gating current in transiently transfected HEK 293 cells. Am J Physiol 270:H1521-H1528.

Barros LF, Hermosilla T, Castro J (2001) Necrotic volume increase and the early physiology of necrosis. Comp Biochem Physiol A Mol Integr Physiol 130:401-409.

Boland B, Kumar A, Lee S, Platt FM, Wegiel J, Yu WH, Nixon RA (2008) Autophagy induction and autophagosome clearance in neurons: relationship to autophagic pathology in Alzheimer's disease. J Neurosci 28:6926-6937.

Borsello T, Croquelois K, Hornung JP, Clarke PG (2003) N-methyl-daspartate-triggered neuronal death in organotypic hippocampal cultures is endocytic, autophagic and mediated by the c-Jun $\mathrm{N}$-terminal kinase pathway. Eur J Neurosci 18:473-485.

Caddy KW, Biscoe TJ (1979) Structural and quantitative studies on the normal C3H and Lurcher mutant mouse. Philos Trans R Soc Lond B Biol Sci 287:167-201.

Carling D (2004) The AMP-activated protein kinase cascade—a unifying system for energy control. Trends Biochem Sci 29:18-24.

Coleman M (2005) Axon degeneration mechanisms: commonality amid diversity. Nat Rev Neurosci 6:889-898.

Dingledine R, Hume RI, Heinemann SF (1992) Structural determinants of barium permeation and rectification in non-NMDA glutamate receptor channels. J Neurosci 12:4080-4087.

Diskin T, Tal-Or P, Erlich S, Mizrachy L, Alexandrovich A, Shohami E, Pinkas-Kramarski R (2005) Closed head injury induces upregulation of Beclin 1 at the cortical site of injury. J Neurotrauma 22:750-762.

Dumesnil-Bousez N, Sotelo C (1992) Early development of the Lurcher cerebellum: Purkinje cell alterations and impairment of synaptogenesis. J Neurocytol 21:506-529.

Dusart I, Guenet JL, Sotelo C (2006) Purkinje cell death: differences between developmental cell death and neurodegenerative death in mutant mice. Cerebellum 5:163-173.

Edinger AL, Thompson CB (2004) Death by design: apoptosis, necrosis and autophagy. Curr Opin Cell Biol 16:663-669.

Erlich S, Alexandrovich A, Shohami E, Pinkas-Kramarski R (2007) Rapamycin is a neuroprotective treatment for traumatic brain injury. Neurobiol Dis 26:86-93.

Forrest D, Yuzaki M, Soares HD, Ng L, Luk DC, Sheng M, Stewart CL, Morgan JI, Connor JA, Curran T (1994) Targeted disruption of NMDA receptor 1 gene abolishes NMDA response and results in neonatal death. Neuron 13:325-338.

Hara T, Nakamura K, Matsui M, Yamamoto A, Nakahara Y, SuzukiMigishima R, Yokoyama M, Mishima K, Saito I, Okano H, Mizushima N (2006) Suppression of basal autophagy in neural cells causes neurodegenerative disease in mice. Nature 441:885-889.

Hicks SW, Machamer CE (2005) Isoform-specific interaction of golgin-160 with the Golgi-associated protein PIST. J Biol Chem 280:28944-28951.

Kabeya Y, Mizushima N, Ueno T, Yamamoto A, Kirisako T, Noda T, Kominami E, Ohsumi Y, Yoshimori T (2000) LC3, a mammalian homologue of yeast Apg8p, is localized in autophagosome membranes after processing. EMBO J 19:5720-5728.

Kabeya Y, Mizushima N, Yamamoto A, Oshitani-Okamoto S, Ohsumi Y, Yoshimori T (2004) LC3, GABARAP and GATE16 localize to autophagosomal membrane depending on form-II formation. J Cell Sci 117: 2805-2812.
Kakegawa W, Kohda K, Yuzaki M (2007) The delta2 “ionotropic” glutamate receptor functions as a non-ionotropic receptor to control cerebellar synaptic plasticity. J Physiol 584:89-96.

Kakegawa W, Miyazaki T, Emi K, Matsuda K, Kohda K, Motohashi J, Mishina M, Kawahara S, Watanabe M, Yuzaki M (2008) Differential regulation of synaptic plasticity and cerebellar motor learning by the C-terminal PDZ-binding motif of GluRdelta2. J Neurosci 28:1460-1468.

Kihara A, Kabeya Y, Ohsumi Y, Yoshimori T (2001) Beclin-phosphatidylinositol 3-kinase complex functions at the trans-Golgi network. EMBO Rep 2:330-335.

Kohda K, Wang Y, Yuzaki M (2000) Mutation of a glutamate receptor motif reveals its role in gating and delta2 receptor channel properties. Nat Neurosci 3:315-322.

Koike M, Shibata M, Tadakoshi M, Gotoh K, Komatsu M, Waguri S, Kawahara N, Kuida K, Nagata S, Kominami E, Tanaka K, Uchiyama Y (2008) Inhibition of autophagy prevents hippocampal pyramidal neuron death after hypoxic-ischemic injury. Am J Pathol 172:454-469.

Komatsu M, Waguri S, Chiba T, Murata S, Iwata J, Tanida I, Ueno T, Koike M, Uchiyama Y, Kominami E, Tanaka K (2006) Loss of autophagy in the central nervous system causes neurodegeneration in mice. Nature 441:880-884.

Levine B, Yuan J (2005) Autophagy in cell death: an innocent convict? J Clin Invest 115:2679-2688.

Li H, Li SH, Yu ZX, Shelbourne P, Li XJ (2001) Huntingtin aggregateassociated axonal degeneration is an early pathological event in Huntington's disease mice. J Neurosci 21:8473-8481.

Long YC, Zierath JR (2006) AMP-activated protein kinase signaling in metabolic regulation. J Clin Invest 116:1776-1783.

Meijer AJ, Codogno P (2007) AMP-activated protein kinase and autophagy. Autophagy 3:238-240.

Mu J, Brozinick JT Jr, Valladares O, Bucan M, Birnbaum MJ (2001) A role for AMP-activated protein kinase in contraction- and hypoxia-regulated glucose transport in skeletal muscle. Mol Cell 7:1085-1094.

Nishiyama J, Miura E, Mizushima N, Watanabe M, Yuzaki M (2007) Aberrant membranes and double-membrane structures accumulate in the axons of Atg5-null Purkinje cells before neuronal death. Autophagy 3:591-596.

Robert A, Hyde R, Hughes TE, Howe JR (2002) The expression of dominant-negative subunits selectively suppresses neuronal AMPA and kainate receptors. Neuroscience 115:1199-1210.

Rubinsztein DC, DiFiglia M, Heintz N, Nixon RA, Qin ZH, Ravikumar B, Stefanis L, Tolkovsky A (2005) Autophagy and its possible roles in nervous system diseases, damage and repair. Autophagy 1:11-22.

Sadasivan S, Waghray A, Larner SF, Dunn WA Jr, Hayes RL, Wang KK (2006) Amino acid starvation induced autophagic cell death in PC-12 cells: evidence for activation of caspase- 3 but not calpain-1. Apoptosis 11:1573-1582.

Sarkar S, Perlstein EO, Imarisio S, Pineau S, Cordenier A, Maglathlin RL, Webster JA, Lewis TA, O'Kane CJ, Schreiber SL, Rubinsztein DC (2007) Small molecules enhance autophagy and reduce toxicity in Huntington's disease models. Nat Chem Biol 3:331-338.

Seeburg PH (1997) Neurodegeneration. A silent channel opens its gates. Nature 388:716-717.

Selimi F, Lohof AM, Heitz S, Lalouette A, Jarvis CI, Bailly Y, Mariani J (2003) Lurcher GRID2-induced death and depolarization can be dissociated in cerebellar Purkinje cells. Neuron 37:813-819.

Shintani T, Klionsky DJ (2004) Autophagy in health and disease: a doubleedged sword. Science 306:990-995.

Sikorska B, Liberski PP, Giraud P, Kopp N, Brown P (2004) Autophagy is a part of ultrastructural synaptic pathology in Creutzfeldt-Jakob disease: a brain biopsy study. Int J Biochem Cell Biol 36:2563-2573.

Slemmer JE, De Zeeuw CI, Weber JT (2005) Don't get too excited: mechanisms of glutamate-mediated Purkinje cell death. Prog Brain Res 148:367-390.

Takano J, Tomioka M, Tsubuki S, Higuchi M, Iwata N, Itohara S, Maki M, Saido TC (2005) Calpain mediates excitotoxic DNA fragmentation via mitochondrial pathways in adult brains: evidence from calpastatin mutant mice. J Biol Chem 280:16175-16184.

Viollet B, Andreelli F, Jorgensen SB, Perrin C, Geloen A, Flamez D, Mu J, Lenzner C, Baud O, Bennoun M, Gomas E, Nicolas G, Wojtaszewski JF, Kahn A, Carling D, Schuit FC, Birnbaum MJ, Richter EA, Burcelin R, 
Vaulont S (2003) The AMP-activated protein kinase alpha2 catalytic subunit controls whole-body insulin sensitivity. J Clin Invest 111:91-98.

Vogel MW, Fan H, Sydnor J, Guidetti P (2001) Cytochrome oxidase activity is increased in $+/ \mathrm{Lc}$ Purkinje cells destined to die. Neuroreport 12:3039-3043.

Vogel MW, Caston J, Yuzaki M, Mariani J (2006) The Lurcher mouse: Fresh insights from an old mutant. Brain Res 1140:4-18.

Wang KK (2000) Calpain and caspase: can you tell the difference? Trends Neurosci 23:20-26.

Wang QJ, Ding Y, Kohtz DS, Mizushima N, Cristea IM, Rout MP, Chait BT, Zhong Y, Heintz N, Yue Z (2006) Induction of autophagy in axonal dystrophy and degeneration. J Neurosci 26:8057-8068.

Wetts R, Herrup K (1982) Interaction of granule, Purkinje and inferior olivary neurons in lurcher chimeric mice. II. Granule cell death. Brain Res 250:358-362.

Wollmuth LP, Kuner T, Jatzke C, Seeburg PH, Heintz N, Zuo J (2000) The Lurcher mutation identifies delta 2 as an AMPA/kainate receptor-like channel that is potentiated by $\mathrm{Ca}^{2+}$. J Neurosci 20:5973-5980.

Woods A, Azzout-Marniche D, Foretz M, Stein SC, Lemarchand P, Ferre P, Foufelle F, Carling D (2000) Characterization of the role of AMPactivated protein kinase in the regulation of glucose-activated gene ex- pression using constitutively active and dominant negative forms of the kinase. Mol Cell Biol 20:6704-6711.

Yu WH, Cuervo AM, Kumar A, Peterhoff CM, Schmidt SD, Lee JH, Mohan PS, Mercken M, Farmery MR, Tjernberg LO, Jiang Y, Duff K, Uchiyama Y, Naslund J, Mathews PM, Cataldo AM, Nixon RA (2005) Macroautophagy — a novel $\beta$-amyloid peptide-generating pathway activated in Alzheimer's disease. J Cell Biol 171:87-98.

Yue Z, Horton A, Bravin M, DeJager PL, Selimi F, Heintz N (2002) A novel protein complex linking the delta 2 glutamate receptor and autophagy: implications for neurodegeneration in lurcher mice. Neuron 35:921-933.

Yuzaki M (2008) New (but old) molecules regulating synapse integrity and plasticity: Cbln1 and the delta2 glutamate receptor. Neuroscience.

Zanjani HS, McFarland R, Cavelier P, Blokhin A, Gautheron V, Levenes C, Bambrick LL, Mariani J, Vogel MW (2009) Death and survival of heterozygous Lurcher Purkinje cells in vitro. Dev Neurobiol.

Zhu JH, Guo F, Shelburne J, Watkins S, Chu CT (2003) Localization of phosphorylated ERK/MAP kinases to mitochondria and autophagosomes in Lewy body diseases. Brain Pathol 13:473-481.

Zuo J, De Jager PL, Takahashi KA, Jiang W, Linden DJ, Heintz N (1997) Neurodegeneration in Lurcher mice caused by mutation in delta2 glutamate receptor gene. Nature 388:769-773. 